\title{
Identification of a nonlinear inertial measuring pressure channel
}

\author{
O. Poliarus, O. Koval, Ya. Medvedovska, Ye. Poliakov, S. lanushkevych \\ Kharkiv National Automobile and Highway University, Yaroslava Mudroho Str., 25, 61002, Kharkiv, Ukraine \\ poliarus.kharkiv@gmail.com
}

\section{Abstract}

The method of nonlinear inertial measuring systems identification is considered in the article on the example of a measuring pressure channel, which consists of a measuring line and a pressure sensor. The latter, as a rule, is a linear system, and the measuring line, which for the pressure channel is a pipe filled with liquid or gas, is projected as a linear system. During the operation, the measuring line gradually becomes contaminated, the liquid partially freezes or air enters it. In this case, the loss of the pressure channel linearity is possible, which in practice, is usually not measured. The proposed method allows to obtain mathematical channel model on the basis of measured input and output signals. It is based on the well-known model, which divides the channel into two virtual blocks, one of which is a nonlinear inertial, and the other is linear inertial. The conversion function of the first block is described by a polynomial of finite degree, and the transforming properties of the second block are described by the convolution integral. This allows to record the signal at the output of the channel in the form of mathematical dependence on the unknown coefficients of the polynomial and parameters of the pulse characteristic of the linear block. Then the distance in the functional space with the quadratic metric between this mathematical dependence and the output signal is minimized. As a result of minimization by the method of the global random search, the polynomial coefficients and the parameters of the impulse response are calculated, which means that the solution of the system identification problem is determined. The received channel model was used for the theoretical determination of the output signal under the already known input signal. The verification of the model based on Fisher's criterion with a significance level of 0.95 confirmed its adequacy.

Keywords: system identification, measuring pressure channel, measuring line, pressure sensor, conversion function, time constant.

\section{Introduction}

The measuring pressure channel (MPC) contains pressure sensors and a measuring line (pipe) that transfers the pressure from the technical object to the sensors. Before measuring, the system is considered as a linear inertial system. As a rule, developers provide the transfer of the input action (signal) to the system output by a linear part of the conversion function of the pressure sensor. In addition, based on a priori information about the width of the spectrum of random input actions, a pressure sensor is selected with an appropriate bandwidth or constant time. During operation, the measuring line is contaminated. The fluid in the measuring line after getting air bubbles into it can be compressed and the model of the measuring pressure channel becomes nonlinear one. This inevitably leads to an increase of measurement uncertainty, if not consider this fact before measurement. In addition, a time constant $\tau_{0}$ can change which leads to inconsistency of the channel bandwidth and the width of the input spectrum. This is also facilitated with the possible increase in the number of frequency components of the spectrum due to the nonlinearity of the channel conversion function. Therefore, to ensure accuracy of measurement information in the measuring channels, it is necessary to check periodically the channel state and its time constant and conversion function. In the presence of obvious deviations $\tau_{0}$ and the form of the conversion function, a dilemma arises: the stopping of the technical object with the subsequent maintenance and repair of the channel or its temporary continuation of work without a significant reduction in the accuracy of the measurement information. Of course, the second option is more economically advantageous. It is possible due to a mathematical model of the measuring channel, which can be obtained with the channel identification.

\section{Analysis of recent research and publications}

The universal model of a dynamic system is the Volterra model, which was considered in many scientific works, for example, in [1]. It can be used for the analysis of a nonlinear inertial measuring channel, but it has extremely large mathematical and computational difficulties in engineering research and therefore so 
far it is not widely used. In systems that have both nonlinear and inertial properties, the Hammerstein model is used instead of the Volterra model, in which the functions of nonlinearity and inertia are artificially spaced [2]. Non-linear identification algorithms for Hammerstein models have several disadvantages. Thus, in the iterative non-linear optimization algorithms, used in identification [3], the problem of convergence is not always well solved due to the local minima of the aim function and the computer time consuming is large. Correlation identification methods [4] put forward stringent requirements for the level of white noise at the input. The methods of least squares and the decomposition of singular values $[5,6]$ have good robustness and convergence, but the identification uses inverted matrices, which in some cases do not exist or are poorly determined. In addition, linear regression is used to approximate the nonlinear conversion function of the measuring channel, which results not only in the increase of model errors and measurements, but also in the shift of the working point in the linearized conversion function and in the possibility of obtaining metrological unreliable results. In general, the process of identifying nonlinear inertial systems is extremely cumbersome. Therefore, neural networks are used for the identification of systems [7]. A well-trained neural network allows quickly getting the result, but in other measurement conditions, which are often encountered in practice, neural network requires re-training. Consequently, the identification of a non-linear inertial measuring system should be carried out in ways that do not statistically linearize the system conversion function. This function is time-dependent and it does not impose strict requirements for the position of the working point on the conversion function. The developed methods should provide acceptable accuracy of signal parameters measurement by identifying a model of the system.

The purpose of the study is to develop a method for identifying a nonlinear inertial measuring pressure channel, to create its model for experimental conditions and to check its adequacy. The information about the model change can be used, firstly, in order not to exceed the permissible pressure measurement errors that were in the system calibration, and secondly, to identify the hidden factors affecting the system, and, thirdly, to estimate the possibility of the model system evolution in the near future.

\section{The proposed method}

The general property of the basic methods of systems identification is the use of the system experimental input and output signals. The identification process depends directly on the goals that put for the achievement results. For our study is important to obtain a model of measuring system that would compensate the increase of pressure measurement errors in service due to loss of system linearity.

For identification, the pressure measuring system with a heterogeneous air measuring line was chosen. It can be easily converted into a nonlinear system by simple valve manipulations inside the line. In experimental studies, a sensor of low pressure MPX5050DP was used as a sensor, which according to the manufacturer [8], has the following characteristics: working pressure $-0 . .50 \mathrm{kPa}$; maximum working pressure $-200 \mathrm{kPa}$; supply voltage $-5 \pm 0.25 \mathrm{~V}$; output voltage - $4500 \mathrm{mV}$; sensitivity - $90 \mathrm{mV} / \mathrm{kPa}$; temperature range of measurements $-0 \ldots 85^{\circ} \mathrm{C}$; relative error of pressure measurement $-2.5 \%$. The choice of the sensor was due to two reasons. The first one

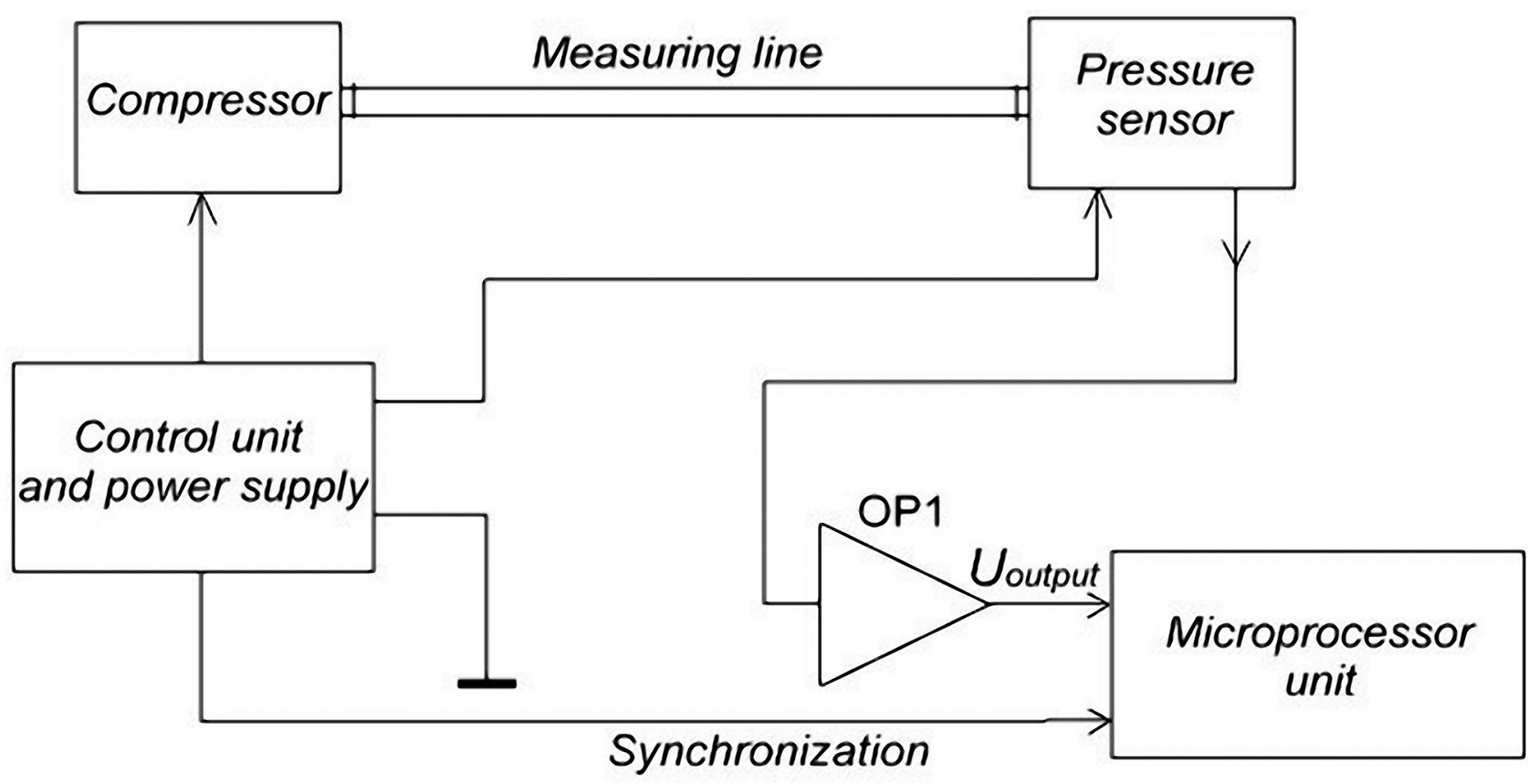

Fig. 1. The structural scheme of the test stand 


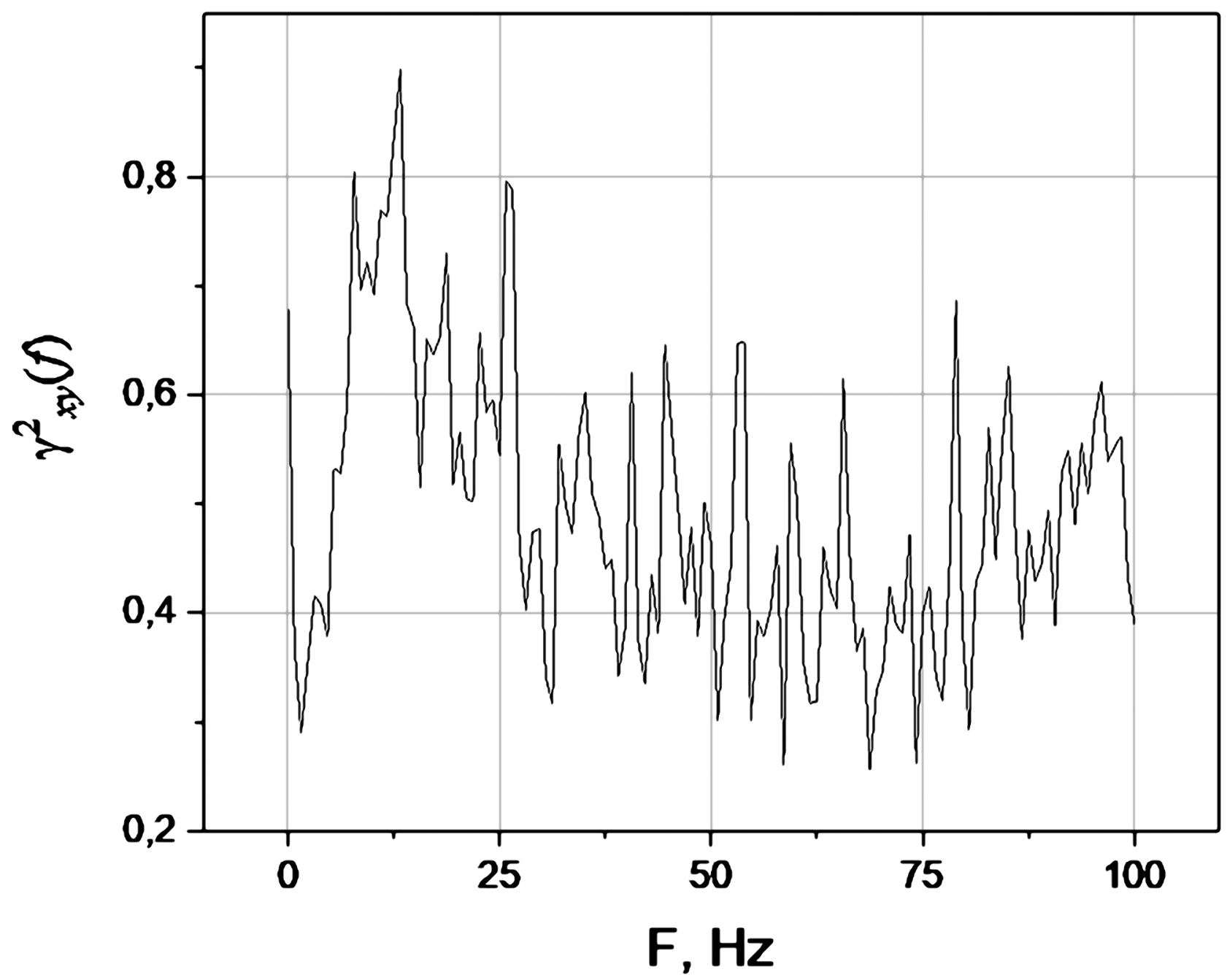

Fig. 2. An example of the coherence function of the input and output signals

is the type of compressor, which could provide a maximum air pressure of $50 \mathrm{kPa}$ and the second is the linearity of the sensor conversion function in the range of measurements. In addition, the need for temperature correction of the relative error of the pressure measurement was also considered.

The conversion function of the pressure sensor MPX5050DP is linear, the range of its input limit values $P_{\min }$ and $P_{\max }$ is $0 \ldots 50 \mathrm{kPa}$, and the output voltage does not exceed $5 \mathrm{~V}$. Due to the high sensitivity of the sensor, which is

$$
\frac{\partial U}{\partial P}=90 \mathrm{mV} / \mathrm{kPa},
$$

even if there is no input signal at the output of the sensor, there are noises with average value $m=40 \mathrm{mV}$. The range of pressure measurements during experimental studies was selected in the range of $2 \ldots 40 \mathrm{kPa}$. To improve the signal-to-noise ratio at output of the pressure sensor, a threshold processing with the constant $U=40 \mathrm{mV}$ corresponding to 13 code units of the analog-to-digital converter was used and implemented in the microcontroller's measurement algorithm. Absolute error of the pressure sensor measurement in the research process was constant throughout the range of measurements and was $\Delta P= \pm 1.25 \mathrm{kPa}$. The temperature coefficient of absolute error of measurement of the pressure sensor, which must be considered in the measurement algorithm of the microcontroller, was also experimentally determined. The research was conducted on a laboratory stand, which looks like a stand described in [9], the structural scheme of which is shown in Fig. 1.

Ten tests were performed for each state of the measuring line and then the measured data were averaged. All measurements were carried out synchronously at a single time scale. The periodicity of measurements in each of 10 series was 30 minutes and the duration of the time sample of each series 1 minute. It was determined with the need for pressure relief to a stable atmospheric one. The discreteness of measurements within one-time sample was $20 \mu \mathrm{s}$. Consequently, for several cases, a plurality of discrete input signals received from the first pressure sensor and a plurality of output signal samples from the second sensor were obtained. These discrete signals were converted then to continuous ones.

Before measurements, it was known that the system was inertial, and the system time constant 
exceeded $20 \mathrm{~ms}$. The conversion function of the measuring system was unknown, that is, we did not have information how this function differed from the linear one. Partially the effect of nonlinearity can be estimated with the degree of distortion of the output signal compared to the input, but such distortion may also be due to the inertia of the system and noise. In [10] it is proposed to use the coherence function $\gamma_{\mathrm{xy}}^{2}(f)$ for this purpose.

An example of the coherence function of input and output signals, that is, the ratio of the mutual spectrum square to the product of these signals' spectra is shown in Fig. 2.

Since $0<\gamma_{\mathrm{xy}}^{2}(f)<1$, according to [10], this means that, firstly, external noise may be present in the measurements, secondly, the output process $y(f)$ is influenced with other input processes, and thirdly, the system is perhaps nonlinear. Since the first two coefficients were eliminated when organizing and conducting an experiment, the main reason for the obtained values is the nonlinearity of the system.

Let us denote $x(t)$ realization of a random input signal, and the output one $-y(t)$. An intermediate signal between two blocks of Hammerstein model (nonlinear without memory and linear with memory) will be denoted as $z(t)$. The signals that were known from the experiment are $x(t)$ and $y(t)$. The intermediate signal is connected with the input one by the polynomial dependence

$$
z(t)=a_{0}+a_{1} x(t)+a_{2} x^{2}(t)+\ldots+a_{n-1} x^{n-1}(t),
$$

where $a_{\mathrm{i}},(i=0, \ldots, n-1)$ - the unknown dimensional coefficients that need to be determined.
The output signal of the measuring channel

$$
y(t)=\int_{-\infty}^{+\infty} z(t) h(t-\tau) d \tau,
$$

where $h(t)$ - pulse response of the linear inertial block of Hammerstein model. For MPC it is determined most often with the exponential function of pressure

$$
h(t)=\frac{A}{\tau_{0}} e^{-\frac{t}{\tau_{0}}},
$$

where $\tau_{0}$ - time constant of the measuring channel, $A$ - amplitude coefficient. In practice, partially known parameters are the coefficients $a_{0}, a_{1}$ in formula (1) and $A, \tau_{0}$ in the formula (3). This is a priori information about the measuring system. Due to the influence of the measuring line, these parameters may differ, and, in addition, new coefficients $a_{\mathrm{i}}(i>1)$ that characterize the nonlinear properties of the system may appear.

The method of these coefficients determining, as well as specifying other parameters, is reduced to the following. The output signal (2) is written considering the series (1), i. e.

$$
\begin{aligned}
y(t)= & a_{0} \int_{-\infty}^{+\infty} h(t-\tau) d \tau+a_{1} \int_{-\infty}^{+\infty} x(t) h(t-\tau) d \tau+ \\
& +a_{2} \int_{-\infty}^{+\infty} x^{2}(t) h(t-\tau) d \tau+\ldots+ \\
& +a_{n-1} \int_{-\infty}^{+\infty} x^{n-1}(t) h(t-\tau) d \tau
\end{aligned}
$$

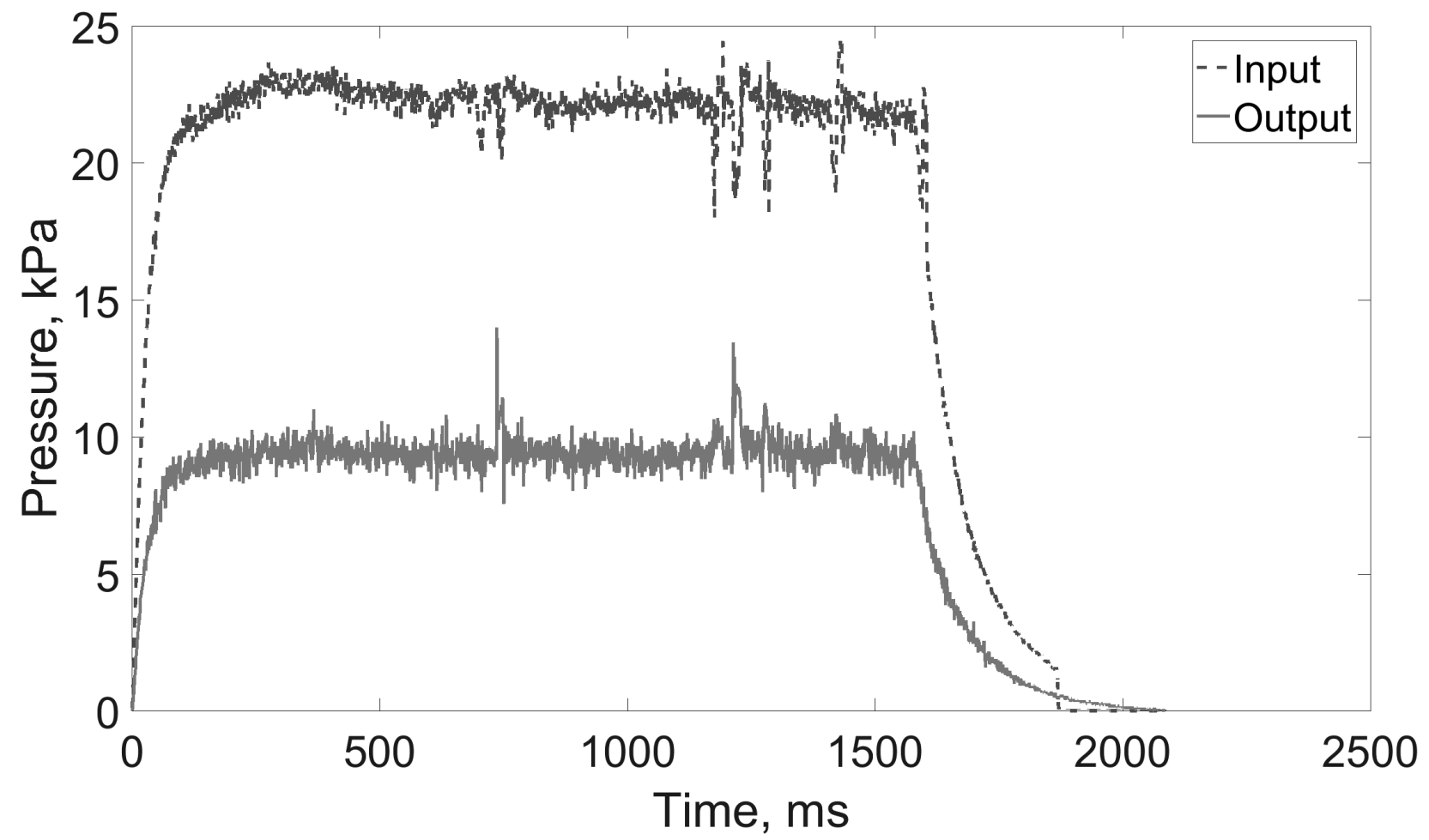

Fig. 3. The examples of input (dash line) and output (solid line) random signals realizations 
Expression (4) describes the theoretical signal $y(t)$, which should coincide with the experimental one $y_{\text {exp }}(t)$. We form a functional characterizing the distance between signals $y(t)$ and $y_{\text {exp }}(t)$ in a functional space with a quadratic metric

$J\left(a_{0}, a_{1}, \ldots, a_{n-1}, A, \tau_{0}\right)=\int_{-\infty}^{\infty}\left[y(t)-y_{\exp }(t)\right]^{2} d t$

Minimization of this functional with the method of random search of the global minimum using a priori information about these parameters allows us to determine the specified parameters, that is, to obtain a model of a nonlinear inertial measuring channel. To complicate the operation of the channel identification algorithm for its verification, a non-stationary signal was generated at the channel input. It was created by switching the valve that was installed in the pipe between the compressor and the measuring channel.

\section{The results of modeling}

The examples of random input and output signals realizations obtained in one of the experiments are shown in Fig. 3.

The model of the measuring pressure channel was obtained using the formulas (1)...(5). The random search for the global minimum of the function (5) of several variables was carried out using a genetic algorithm. For a particular experiment, it turned out that the coefficients in the formula (1) and the constant time of all the MPC are as follows: $a_{0}=1$, $a_{1}=0.5, a_{2}=0.2, \tau_{0} \approx 30 \mathrm{~ms}$. The coefficients $a_{3}, a_{4} \ldots, a_{n-1}$ for this experiment are close to zero and was not used for the channel identification. The slope of the linear part of the MPC conversion function is determined by the coefficient $a_{1}=0.5$. A small value of the coefficient $a_{2}=0.2$ indicates that the channel is nonlinear, but one should not expect large nonlinear distortions of the signal in the range of variations of its amplitude. The specific magnitude of signal distortion in the measuring channel can be estimated only for a specific problem, when the characteristics of the signals and the channel are known, as well as the requirements for them. The small value of the constant time of the measuring channel means the presence of a wide bandwidth of the MPC, and, therefore, small distortions of the input signal due to the inertia of the channel.

The range of search parameters of the MPC model was limited to a priori information about the process. For example, the time constant of a MPC with the ideal measuring line is equal to the time constant of the MPX5050DP sensor used in the experiment, that is, $\tau_{0} \approx 20 \mathrm{~ms}$. The inhomogeneous measuring line

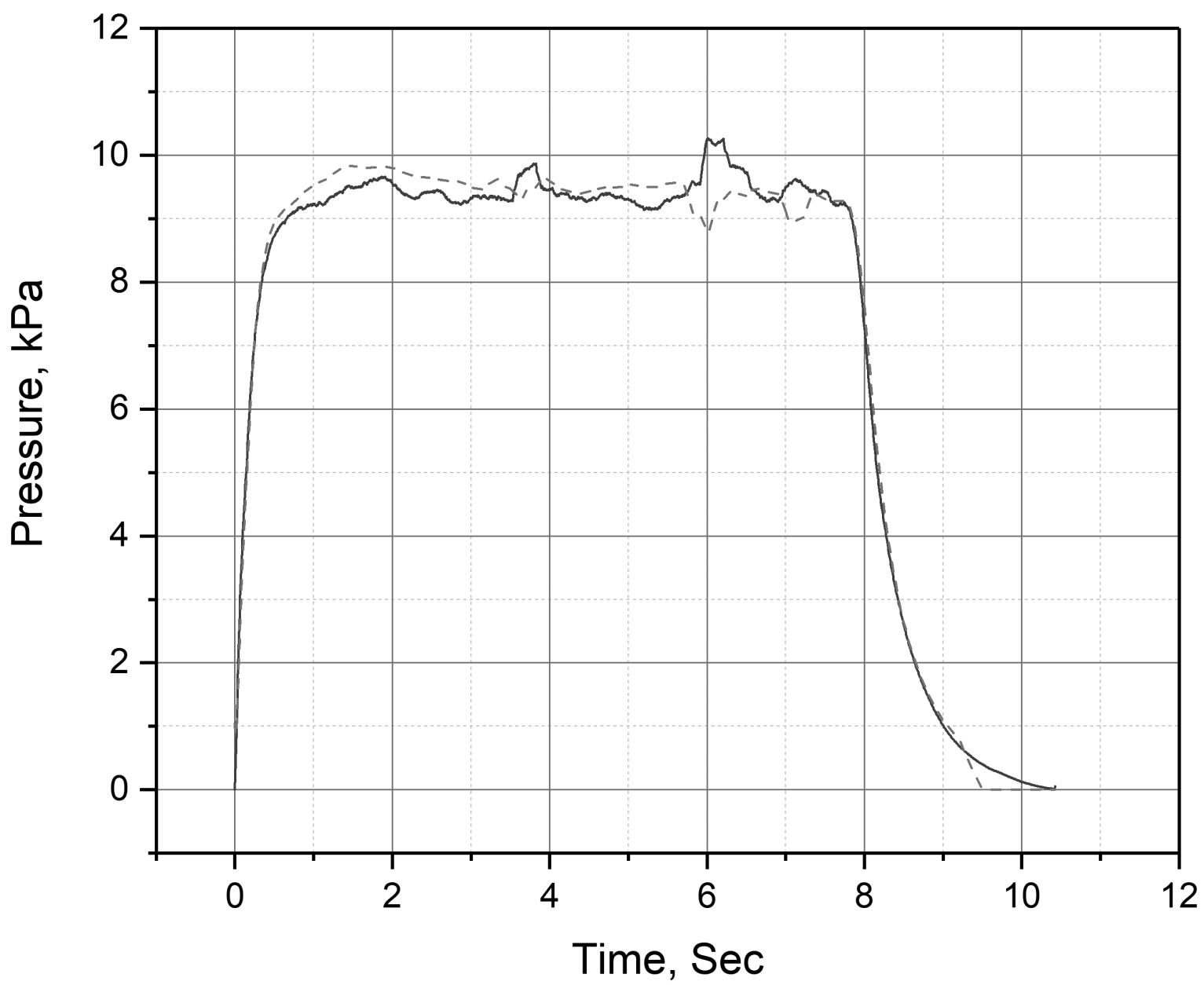

Fig. 4. The smoothed realizations of the experimental (solid line) and the theoretical (dashed line) signals 


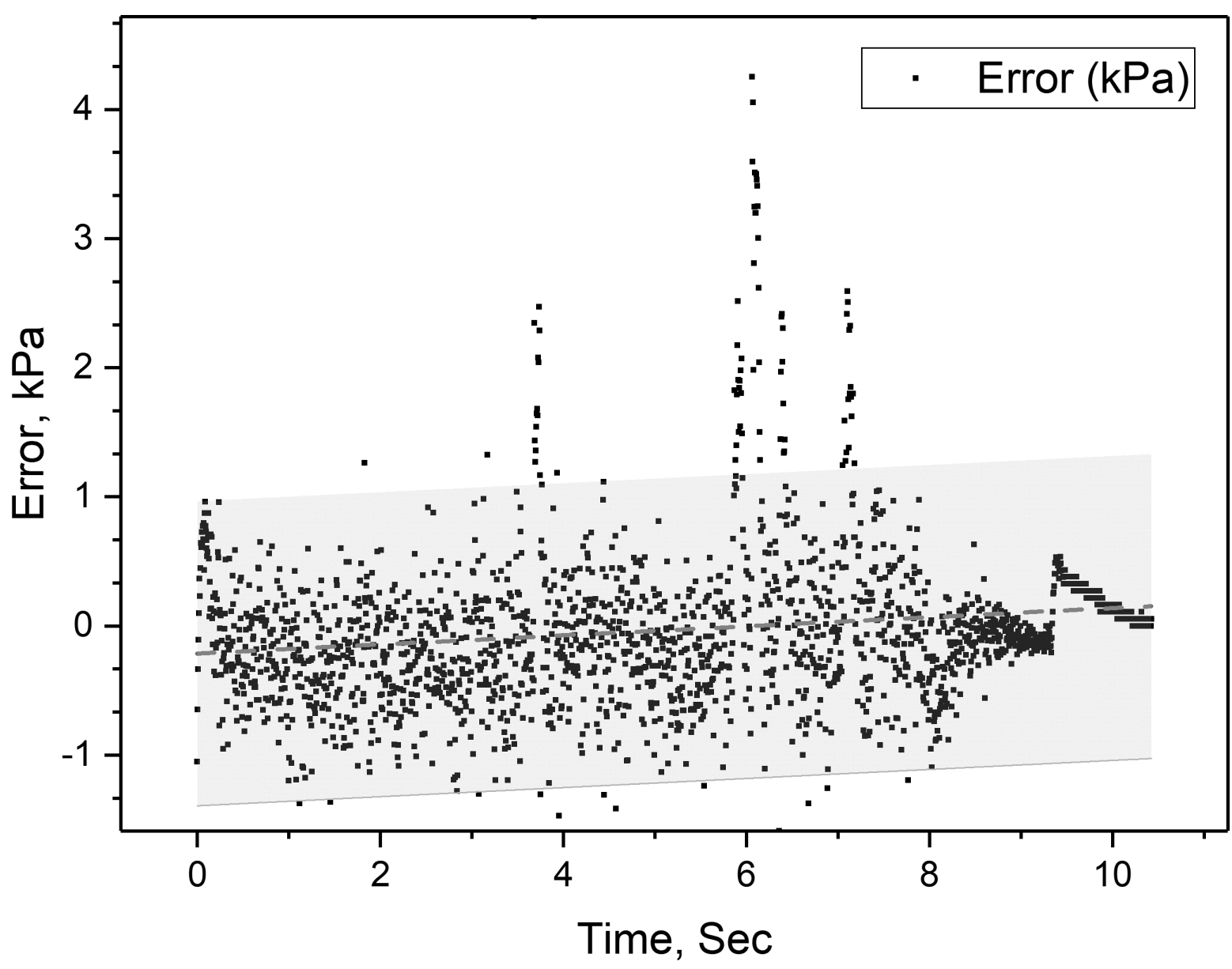

Fig. 5. An example of a confidence interval for error estimating the output signal based on the developed model

(a pipe filled with air under pressure) increased a time constant and the latter was determined during the minimization of the function (5). Consequently, for this experiment, the initial time constant of the channel $\tau_{0} \approx 20 \mathrm{~ms}$ is increased to $\tau_{0} \approx 30 \mathrm{~ms}$.

After obtaining the MPC model for one particular experiment, this model was used to analyze the results of another experiment conducted in similar conditions, that is, the channel model was the same. For this purpose, the input signal $x(t)$ was measured and further converted into a signal $y(t)$, using formulas (2)...(5). This signal is theoretical (calculated) one. It was compared with the experimental one $y_{\exp }(t)$, that is, with the measured signal. These signals do not match, since the experimental signal is measured together with the noise. In the channel model, obtained using the genetic algorithm, the coefficients $\left(\tau_{0}, a_{\mathrm{i}}\right)$ do not consider the noise components, that is, the genetic algorithm has a filtering property. If the experimental signal is smoothed with the method of "sliding window", then the noise of the output signal is significantly reduced. The smoothed realizations of experimental and theoretical signals are shown in Fig. 4. All signals are calculated for this model of MPC.

As it can be seen from Fig. 4, the signals are close in shape. Calculated values of Fisher's criterion (for example, 273.38 and 64.70 for two different conditions) appeared to be much more tabular critical values with a significance level of 0.95 . All this indicates that the model of the pressure measuring channel is adequate. The calculation of the confidence interval shows (Fig. 5) that with the probability of 0.95 errors of evaluation of the output signal based on the model does not exceed $10 \%$, and in most cases they do not reach $5 \%$.

Consequently, the identification problem is solved by the proposed method with high reliability.

\section{Conclusion}

A method for the identification of a measuring pressure channel is proposed in the article. It does not require the linearization of the conversion function. This function, as well as the time constant of the channel during operation, may change. The measuring channel model will also change, ensuring the stability of the channel characteristics, and the maximum measurement errors caused by changing the model will not exceed $10 \%$. The method is appropriate to use in all non-linear measuring information systems with or without memory. Finally, the method allows to detect and evaluate the nonlinearity of the measuring channel by the value of the coefficients of the conversion function, which is described by the polynomial. The small values of the coefficients of a polynomial at the second, third, and so forth degrees indicate the linearity of the transformation function. 


\title{
Идентификация нелинейного инерционного измерительного канала давления
}

\author{
А.В. Полярус, А. А. Коваль, Я.С. Медведовская, Е.О. Поляков, \\ С.Д. Янушкевич
}

Харьковский национальный автомобильно-дорожный университет, ул. Ярослава Мудрого, 25, 61002, Харьков, Украина poliarus.kharkiv@gmail.com

\section{Аннотация}

Рассматривается метод идентификации нелинейных инерционных измерительных систем на примере измерительного канала давления, состоящего из измерительной линии и датчика давления. Последний, как правило, является линейной системой, а измерительная линия, которая для канала давления является трубой, заполненной жидкостью или газом, проектируется как линейная система. В процессе эксплуатации измерительная линия постепенно загрязняется, в жидкость попадает воздух или она частично замерзает. В этом случае возможна потеря линейности канала давления, которая на практике, как правило, не измеряется. Предложенный метод позволяет на основе измеренных входного и выходного сигналов получить математическую модель канала. В ее основе лежит известная модель Гаммерштейна, которая разделяет канал на два виртуальных блока, один из которых является нелинейным инерционным, а второй - линейным инерционным. Функция преобразования первого блока является полиномом конечной степени, а преобразующие свойства второго блока описываются интегралом свертки. Это позволяет записать сигнал на выходе канала в виде математической зависимости с неизвестными коэффициентами полинома и параметрами импульсной характеристики линейного блока. Далее минимизируется расстояние в функциональном пространстве с квадратичной метрикой между указанной математической зависимостью и выходным сигналом. В результате минимизации этого расстояния методом глобального случайного поиска находятся коэффициенты полинома и параметры импульсной характеристики, что свидетельствует о решении задачи идентификации системы. Для этого была создана экспериментальная измерительная линия, заполненная воздухом под давлением, которое измерялось двумя одинаковыми датчиками, расположенными на входе и выходе линии. Проверка модели на основе критерия Фишера с уровнем значимости 0.95 подтвердила ее адекватность.

Ключевые слова: идентификация систем, измерительный канал давления, измерительная линия, датчик давления, функция преобразования, постоянная времени.

\section{Ідентифікація нелінійного інерційного вимірювального каналу тиску}

\author{
О.В. Полярус, О.А. Коваль, Я.С. Медведовська, Є.О. Поляков, \\ С.Д. Янушкевич
}

Харківський національний автомобільно-дорожній університет, вул. Ярослава Мудрого, 25, 61002, Харків, Україна poliarus.kharkiv@gmail.com

\section{Анотація}

Розглядається метод ідентифікації нелінійних інерційних вимірювальних систем на прикладі вимірювального каналу тиску, який складається з вимірювальної лінії та давача тиску. Останній, як правило, є лінійною системою, а вимірювальна лінія, яка для каналу тиску є трубою, заповненою рідиною або газом, проектується як лінійна система. У процесі експлуатації вимірювальна лінія поступово забруднюється, в рідину потрапляє повітря або вона частково замерзає. У цьому випадку можлива втрата лінійності каналу тиску, яка на практиці, як правило, не вимірюється. Запропонований метод дозволяє на основі виміряних вхідного і вихідного сигналів отримати математичну модель каналу. В іiі основі лежить відома модель Гаммерштейна, яка розділяє канал на два віртуальних блоки, один з яких є нелінійним інерційним, а другий - лінійним інерційним. Функція перетворення першого блоку описується поліномом кінцевого ступеня, а перетворюючі властивості другого блоку описуються інтегралом згортки. Це дозволяє записати сигнал на виході каналу у вигляді математичної залежності з невідомими коефіцієнтами полінома і параметрами імпульсної характеристики лінійного блоку. Далі мінімізується відстань у функціональному просторі з квадратичною метрикою між зазначеною математичною залежністю і вихідним сигналом. У результаті мінімізації 
цієї відстані методом глобального випадкового пошуку знаходяться коефіцієнти полінома і параметри імпульсної характеристики, що свідчить про рішення задачі ідентифікації системи. Для цього було створено експериментальну вимірювальну лінію, заповнену повітрям під тиском, який вимірювався двома однаковими давачами, що розташовані на вході і виході лінії. Отримана модель каналу використовувалася для теоретичного визначення вихідного сигналу при відомому вже іншому вхідному сигналі. Перевірка моделі на основі критерія Фішера 3 рівнем значущості 0.95 підтвердила іiї адекватність.

Ключові слова: ідентифікація систем, вимірювальний канал тиску, вимірювальна лінія, давач тиску, функція перетворення, стала часу.

\section{References}

1. Novak A. Identification of Nonlinear Systems: Volterra Series Simplification. Acta Polytechnica, 2007, vol. 47, no. 4-5, pp. 72-75.

2. Er-Wei Bai, Minyue Fu. A Blind Approach to Hammerstein Model Identification. IEEE Transactions on Signal Processing, 2002, vol. 50, no. 7, pp. 291-304.

3. Vörös J. An iterative method for Hammerstein-Wiener systems parameter identification. Journal of electrical engineering, 2004, vol. 55, no. $11-12$, pp. 328-331.

4. Billings S.A. Identification of nonlinear systems a survey. IEE Proceedings D: Control Theory and Applications, 1980, vol. 127, issue 6, pp. 272-285.

5. Brouri A., Giri F., Mkhida A. et al. Identification of Nonlinear Systems Structured by Hammerstein-Wiener Model. World Academy of Science, Engineering and Technology, International Journal of Electrical, Computer, Energetic, Electronic and Communication Engineering, 2014, vol. 8, no. 5, pp. $738-742$.
6. Kerschen G. et al. The Method of Proper Orthogonal Decomposition for Dynamical Characterization and Order Reduction of Mechanical Systems: An Overview. Nonlinear Dynamics, 2005, vol. 41, pp. 147-169.

7. Chen S. et al. Practical identification of NARMAX models using radial basic functions. International Journal of Control, 1990, vol. 52, no. 6, pp. 1327-1380.

8. MPX5050. Freescale Semiconductor. Technical Data Pressure Sensors. Integrated Silicon Pressure Sensor On-Chip Signal Conditioned, Temperature Compensated and Calibrated. Rev 9, 05/2007, http://www.freescale.com/support

9. Koval A. O., Koval O.A. Prostorovo rozpodileni intelektualni vymiriuvalni systemy: monohrafiia [Spatially distributed intelligent measuring information systems: monograph]. Kharkiv, Lider, 2017. 146 p. (in Ukrainian).

10. Bendat J.S. Spectral Techniques for Nonlinear System Analysis and Identification. Shock and Vibration, 1993, vol. 1, no. 1, pp. 21-31. 